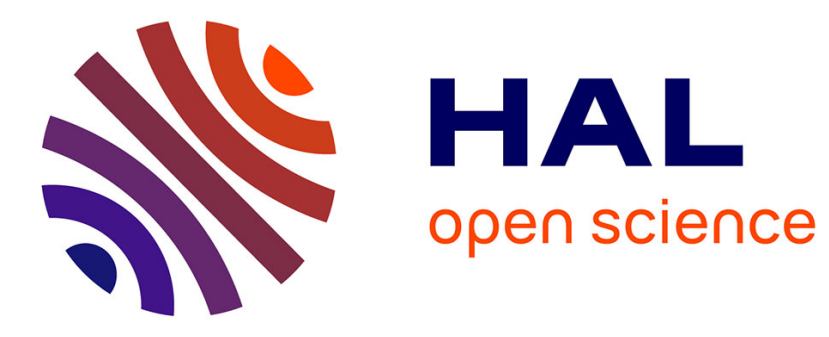

\title{
Fluoxetine effects assessment on the life cycle of aquatic invertebrates
}

\author{
Alexandre R.R. Pery, M. Gust, B. Vollat, R. Mons, M. Ramil, G. Fink, T.A. \\ Ternes, Jeanne Garric
}

\section{To cite this version:}

Alexandre R.R. Pery, M. Gust, B. Vollat, R. Mons, M. Ramil, et al.. Fluoxetine effects assessment on the life cycle of aquatic invertebrates. Chemosphere, 2008, 73 (3), pp.300-304. 10.1016/j.chemosphere.2008.06.029 . ineris-00961924

\section{HAL Id: ineris-00961924 \\ https://hal-ineris.archives-ouvertes.fr/ineris-00961924}

Submitted on 20 Mar 2014

HAL is a multi-disciplinary open access archive for the deposit and dissemination of scientific research documents, whether they are published or not. The documents may come from teaching and research institutions in France or abroad, or from public or private research centers.
L'archive ouverte pluridisciplinaire HAL, est destinée au dépôt et à la diffusion de documents scientifiques de niveau recherche, publiés ou non, émanant des établissements d'enseignement et de recherche français ou étrangers, des laboratoires publics ou privés. 


\section{Garric $^{1}$}

$4{ }^{1}$ Laboratoire d'écotoxicologie, Cemagref, 3b quai Chauveau 69009 Lyon, France.

$5 \quad 2$ INERIS, Institut National de l'Environnement Industriel et des Risques, Unité de

6 Toxicologie Expérimentale, 60550 Verneuil en Halatte, France.

$7 \quad{ }^{3}$ Federal Institute of Hydrology (BFG), D-56068 Koblenz, Am Mainzer Tor 1, Germany.

8 *Corresponding author. Tel +33 3445561 26; Fax +33 3445568 00; E-mail address:

9 alexandre.pery@ineris.fr 


\section{Abstract}

Fluoxetine is a serotonin re-uptake inhibitor, generally used as an antidepressant. It is suspected to provoke substantial effects in the aquatic environment. This study reports the effects of fluoxetine on the life cycle of four invertebrate species, Daphnia magna, Hyalella azteca and the snail Potamopyrgus antipodarum exposed to fluoxetine spiked-water and the midge Chironomus riparius exposed to fluoxetine-spiked sediments. For D. magna, a multigenerational study was performed with exposition of newborns from exposed organisms. Effects of fluoxetine could be found at low measured concentrations (around $10 \mu \mathrm{g} \mathrm{L}^{-1}$ ), especially for parthenogenetic reproduction of $D$. magna and $P$. antipodarum. For daphnids, newborns length was impacted by fluoxetine and the second generation of exposed individuals showed much more pronounced effects than the first one, with a NOEC of $8.9 \mu \mathrm{g} \mathrm{L}^{-1}$. For P. antipodarum, significant decrease of reproduction was found for concentrations around $10 \mu \mathrm{g} \mathrm{L}^{-1}$. In contrast, we found no effect on the reproduction of $H$. azteca but a significant effect on growth, which resulted in a NOEC of $33 \mu \mathrm{g} \mathrm{L}^{-1}$, expressed in nominal concentration. No effect on C. riparius could be found for measured concentrations up to $59.5 \mathrm{mg} \mathrm{kg}^{-1}$. General mechanistic energybased models showed poor relevance for data analysis, which suggests that fluoxetine targets specific mechanisms of reproduction.

Keywords : invertebrates, fluoxetine, pharmaceuticals, sublethal effects, multi-generational test, mechanistic models. 


\section{Introduction} (n)

For the past few years, there has been a growing concern about ecotoxicological risk of pharmaceuticals. Indeed, human medicines have been detected in many countries in sewage treatment plant effluents, surface waters, seawaters, groundwater and some drinking waters (Fent et al., 2006). As pharmaceuticals are present at relatively low levels in the environment, risk for acute toxic effects is unlikely, but chronic environmental toxic effects cannot be excluded (Carlsson et al., 2006). However, little is known about the chronic effects of these substances. Moreover, environmental risk assessment based on acute data is inappropriate (Ferrari et al., 2004). For instance, carbamazepine and propanolol would be inaccurately identified as having negligible risks in France and Germany. There is a real lack of long term effects studies, in particular chronic data on the entire life cycle and investigation of multigenerational effects (Fent et al., 2006).

Fluoxetine is a serotonin re-uptake inhibitor. It is apparently the most acute toxic human pharmaceuticals reported so far (Fent et al., 2006), which makes necessary more studies about risks of low levels of exposure. In terms of environmental concentrations, Kolpin et al. (2002) estimated at $0.012 \mu \mathrm{g} \mathrm{L}^{-1}$ the median concentration of fluoxetine in U.S. streams. In terms of chronic effects, the recently published data on the effects of fluoxetine to invertebrates provide contradictory information. Flaherty and Dodson (2005) found an enhancement of reproduction for Daphnia magna exposed to a concentration of $36 \mu \mathrm{g} \mathrm{L}^{-1}$. In contrast, Brooks et al. (2003) found a reproduction decrease for Ceriodaphnia dubia with a NOEC of $56 \mu \mathrm{g} \mathrm{L}^{-1}$ and a LOEC of $112 \mu \mathrm{g} \mathrm{L}^{-1}$. Henry et al. (2004) also found reproduction decrease for the same species with a NOEC of $89 \mu \mathrm{g} \mathrm{L}^{-1}$ and a LOEC of $447 \mu \mathrm{g} \mathrm{L}^{-1}$. Brooks et al. (2003) derived growth LOECs for Chironomus tentans and Hyalella azteca of respectively 1.3 and $5.6 \mathrm{mg} \mathrm{kg}^{-1}$ sediment, but Nentwig (2007) did not find any significant effect on 
Chironomus riparius for concentrations up to $5.86 \mathrm{mg} \mathrm{kg}^{-1}$ sediment. This author obtained an extremely low LOEC of $0.47 \mu \mathrm{g} \mathrm{L}^{-1}$ for the reproduction of the snail Potamopyrgus antipodarum, comparable to concentrations measured in surface water.

Toxic effects of fluoxetine on invertebrates are consequently still worth being studied.

We selected four invertebrates, with the following criteria: first, we tested species for which at least one test result is available in the literature to allow comparisons between our data and data from other studies; second, as past studies indicated that the sublethal effects of fluoxetine are likely to be on reproduction, we tried to have different reproduction strategies (sexual reproduction and parthenogenesis). We consequently used a large test battery encompassing several phylogenetic groups. The species selected were then Chironomus riparius for sediment borne exposure, the crustacean Daphnia magna and Hyalella azteca, and the mollusc gastropod Potamopyrgus antipodarum concerning water borne exposure. This selection for water borne exposure is relevant to cover a large range of invertebrate sensitivity for organic compounds, as presented by Wogram and Liess (2001). Indeed, these authors showed that, relative to organic compounds, amphipoda are significantly more sensitive than daphnids and that gastropoda are significantly less sensitive than daphnids. We plan here to investigate effects on all the components of the life cycle of our species. In particular, effects on adults survival and reproduction as well as effects on juveniles survival and growth have been assessed. Moreover, for one of the species (Daphnia magna), fitness of the newborns produced during exposure and exposed themselves at the same concentration as their mother was assessed, to account for subtle effects on reproduction (like malformation) which would be undetectable with results expressed only in terms of numbers of newborns. Finally, the growth and reproduction data were analyzed using energy-based models, DEBtox (Kooijman and Bedaux, 1996). These models permit to estimate parameters not dependent on time, which is valuable to assess effects for long term exposure, and they allow insides 
relative to the physiological mode of action of the compound (Kooijman and Bedaux, 1996; Péry et al., 2003).

\section{Materials and Methods}

\subsection{Chemical substance}

Fluoxetine-HCL was used for all ecotoxicity tests (CAS 59333-67-4). It was purchased from Interchim (Montluçon, France ; product number 09674, batch number RD0001).

\subsection{Chironomus riparius tests}

Larvae were exposed to fluoxetine-spiked sediment. Sediment has been taken from Port-Galland, a tributary of the river Ain (France). This sediment has been monitored for years by Cemagref. Chemicals concentration are at low level and it has never been toxic to sediment organisms. Sediments were $2 \mathrm{~mm}$ sieved and homogenised before use. Organic carbon content is $3 \%$, organic nitrogen content is $0.35 \%$. Water was constituted of $1 / 4$ water from a spring, situated under our laboratory, added to demineralised water, resulting in $\mathrm{pH}$ of 7.8 and conductivity of $450 \mu \mathrm{S} \mathrm{cm}^{-1}$. Sediments were spiked with fluoxetine 10 days before starting the tests. Fluoxetine (Interchim, Montluçon, France) was introduced in $0.5 \mathrm{~L}$ water at the concentration corresponding to the chosen nominal exposure concentrations and mixed with $1.5 \mathrm{~kg}$ wet sediment. Tested exposure concentrations were 1.2, 3.7, 11, 33, 100 and 1000 $\mathrm{mg} \mathrm{kg}^{-1} \mathrm{~d}$.w., the latest being the concentration for which a compound is considered as safe if no significant effect occur at this exposure concentration (OECD, 2004). Sediments were transferred in beakers three days before starting tests. There were ten beakers per concentration. We put $0.1 \mathrm{~L}$ sediment and $0.4 \mathrm{~L}$ water in these beakers. The beakers were set in a water bath at $21^{\circ} \mathrm{C}$ with a $16: 8 \mathrm{~h}$ light:dark photoperiod. Conductivity, temperature, $\mathrm{pH}$, 
amount of dissolved oxygen were measured daily. We used an aeration system (air introduced through a Pasteur pipette in each beaker) to maintain oxygen level.

The experiment was initiated with two-day-old larvae (end of first instar) from our

laboratory culture. We put ten larvae per beaker. Length at the beginning of the test, measured on 20 organisms, was $1.7+/-0.1 \mathrm{~mm}$. Organisms were fed daily with $0.6 \mathrm{mg}$ per larva

112 Tetramin ${ }^{\circledR}$ fish food.

At day 7, survivor and growth were monitored by sampling five beakers per

114 concentration. Individuals were counted, killed using formaldehyde, then length was

115 measured using a binocular microscope. Emergence was monitored for the five remaining

116 beakers per concentration which had been covered to prevent organisms from escaping. The

117 females were then put into $1 \mathrm{~L}$ mating chambers, with $0.1 \mathrm{~L}$ water, with males from

118 laboratory culture in a ratio of three males per female as described by Péry et al. (2002).

119 After mating and oviposition, each egg mass was removed and put into a $5 \mathrm{~mL}$ tube with 2

$120 \mathrm{~mL} \mathrm{H}_{2} \mathrm{SO}_{4}, 2 \mathrm{~N}$ overnight and the number of eggs was counted.

\subsection{Hyalella azteca tests}

Amphipods were exposed to fluoxetine-spiked water. Experimental protocol was the same as in Péry et al. (2005) : amphipods were exposed in beakers and an artificial nylonshelter was introduced at the bottom of each beaker. The beakers were set in a water bath at $21{ }^{\circ} \mathrm{C}$ with a $16: 8 \mathrm{~h}$ light:dark photoperiod. Test water in the beakers was continuously renewed (four renewals a day): for each concentration, there was a continuous pumping of

128 clean water (same as for $C$. riparius) and stock solution at a speed calculated to obtained the

129 required exposure concentration and then mixed in a bottle. Stock solution was protected from

130 light and renewed every three days. The nominal exposure concentrations were 3.7, 11, 33

131 and $100 \mu \mathrm{g} \mathrm{L}^{-1}$. Specific conductivity, temperature, $\mathrm{pH}$, dissolved oxygen were measured 
132 daily. Organisms were fed daily with $0.16 \mathrm{mg}$ Tetramin ${ }^{\circledR}$ per individual. Two experiments

133 were conducted. In the first one, young organisms (between 7 and 9 days old, mean length

$1341.69+/-0.17 \mathrm{~mm}$ ) selected in our laboratory culture were exposed (ten per beaker) and length

135 was measured every 7 days to assess effects on growth. Length measurements were

136 performed on the dorsal side from the base of the first antenna to the end of the next to last

137 segment, using an image analysis method (Sigma Scan Pro 5.0, SPSS Inc., Chicago). In the

138 second one, we exposed five precopula (one male and one female, resulting in ten organisms

139 per beaker) taken from our laboratory culture per beaker during 28 days, and we monitored

140 reproduction every week. For each experiment, there was four replicates per concentration.

142 2.4. Daphnia magna tests

143 Organisms were exposed individually in $100 \mathrm{~mL}$-bottles which contained $80 \mathrm{~mL}$ of 144 solution. There were ten replicates per concentration. Tested fluoxetine concentrations were 0 ,

$1453,10,30,100$ and $300 \mu \mathrm{g} \mathrm{L} \mathrm{L}^{-1}$. Test duration was $21 \mathrm{~d}$, temperature was maintained at $20{ }^{\circ} \mathrm{C}$ 146 by putting the bottles in temperature-controlled chambers, water (M4 medium, as 147 recommended by ISO 10706) was renewed every day. Daphnids length was measured at days 1487,14 and 21 using image analysis and reproduction (number of newborns) was monitored 149 every day. Length of the newborns was measured for the third brood. Food was algae 150 Pseudokirchneriella subcapitata from our laboratory culture. Each organism received $15110^{7}$ algal cells per day the two first days, $2.10^{7}$ algal cells per day the three following days, 3. $15210^{7}$ algal cells per day the two following days and $4.10^{7}$ algal cells per day until the end of the 153 test. These feeding conditions are ad libitum conditions, as it has been chosen by previous 154 tests (unpublished results).

155 To assess effects on two generations, an experiment in the same conditions was 156 performed with newborns from the fifth brood. This experiment with the newborns started 
157 exactly the day when the experiment with their mother ended. There was not enough

158 surviving newborns to start this new test for nominal concentration $300 \mu \mathrm{g} \mathrm{L}^{-1}$.

Snails from the species Potamopyrgus antipodarum came from our laboratory culture.

162 The test beakers were filled with $0.5 \mathrm{~L}$ fluoxetine-spiked water (the same as for amphipods),

163 three days before the beginning of the tests. The beakers were set in a water bath at $21{ }^{\circ} \mathrm{C}$

164 with a 16:8 h light:dark photoperiod. The exposure system was the same as for H. azteca. The nominal exposure concentrations were $3.7,11,33$ and $100 \mu \mathrm{g} \mathrm{L}^{-1}$. Specific conductivity, temperature, $\mathrm{pH}$, dissolved oxygen were measured daily. Organisms were fed with $0.6 \mathrm{mg}$

167 Tetramin $®$ fish food (Tetrawerke, Melle, Germany) per individual per day. We performed two experiments, one to assess effects on growth, the other one to assess effects on reproduction. Growth was monitored every week through shell length measurements using a binocular. At the beginning of the growth test, each beaker contained ten organisms, which

171 had been selected in the culture according to their length $(0.48+/-0.026 \mathrm{~mm})$. Reproduction was monitored once a week, by counting and removing all newborns using a binocular. The test was initiated with individual adult length superior to $4 \mathrm{~mm}$ at the beginning of the test, and also ten individuals per replicate. For each experiment, there were three replicates per concentration. The experiments lasted six weeks.

\subsection{Analytical Procedures}

Spiked water was sampled for all exposure concentrations in the $D$. magna and $P$. antipodarum tests at day 10 for daphnids and day 42 for snails. We could not have chemical measurements for amphipod tests. To get enough volume to perform chemical measurements, 
181

182

waters for all replicates of a given concentration were pooled. Spiked sediments were sampled for all concentrations at the end of the toxicity test.

Water samples (10-250 mL), adjusted to $\mathrm{pH} 3$ with sulphuric acid, were spiked with the surrogate standard fluoxetine-d5 (Isotec, Miamisburg, USA). Samples were enriched at a flow rate of 10-20 mL $\mathrm{min}^{-1}$ (ca. 200 mbar) with OASIS HLB SPE cartridges (200 mg, 30 $\mu \mathrm{m}$, Waters, Milfort, USA) and the SPE material was dried for $1 \mathrm{~h}$ under a nitrogen stream. Fluoxetine was eluted using 4 x $2 \mathrm{~mL}$ of methanol/acetic acid (98/2, v/v). After blowing down to $100 \mu \mathrm{L}$ the samples extracts, they were reconstituted to $1 \mathrm{~mL}$ of the $\mathrm{LC}$ eluent $\mathrm{A}$ (see below).

Sediment samples $(1 \mathrm{~g})$ were spiked with the surrogate standard fluoxetine-d5 and extracted by pressurized liquid extraction (PLE) with $\mathrm{MeOH} /$ water/acetic acid (49:49:2) at 100 bar and $120^{\circ} \mathrm{C}$ during two static cycles of five min. Afterwards, the extract was made up to $50 \mathrm{~mL}$ and one aliquot of $0.1-1 \mathrm{~mL}$ diluted in $500 \mathrm{~mL}$ of groundwater. SPE clean-up was carried out with OASIS HLB cartridges eluted with MeOH-MTBE (95:5).

The sample extracts were measured by LC tandem MS (Agilent 1100 with degasser, quaternary pump and autosampler, Agilent Technologies, Waldbronn, Germany/API 4000 with ESI ionization, Applied Biosystems, Foster City, CA, USA) operating in the positive ion mode using multiple reaction monitoring (MRM). Chromatographic separation took place at room temperature by means of a Synergi Polar RP 80A column $(150 \times 3 \mathrm{~mm}, 4 \mu \mathrm{m})$ (Phenomenex ${ }^{\circledR}$, Aschaffenburg, Germany). A mixture of $20 \mathrm{mM}$ ammonia solution (pH 5.7 adjusted with acetic acid): acetonitrile (98:2) (A) and a mixture of A:acetonitrile (2:3) (B) were used as mobile phases. Two MRM transitions were monitored for each substance for identification and quantification of the analytes (fluoxetine: 310/44 and 310/148 amu; fluoxetine-d5: 315/44 and 315/143 amu). 
205 Calibration curves showed a good correlation in the range 5-2000 ng.mL ${ }^{-1}$. Limits of 206 quantification for fluoxetine in sediment and water samples were $10 \mathrm{ng} . \mathrm{g}^{-1}$ and $5 \mathrm{ng} . \mathrm{L}^{-1}$, 207 respectively.

\subsection{Statistical analysis}

210 To analyse the data, we used standard methods (ANOVA, Dunnett-t tests) but also 211 DEBtox models (See a complete description in Kooijman and Bedaux, 1996 and in the OECD 212 guideline about statistics in ecotoxicology (OECD, 2006)). These models are based on the 213 DEB theory (Kooijman, 2000), which describes growth and reproduction as a function of 214 bioenergetics parameters like for instance costs of maintenance or food assimilation rate. 215 Effects on growth and reproduction are described as the consequences of effects on one of 216 these bioenergetics parameters. These effects are proportional to the difference between accumulated compound concentration and a threshold concentration, called the NEC (No Effect Concentration). The estimate of this threshold concentration, obtained through maximum likelihood methods, does not depend on the duration of the test.

\section{Results}

\subsection{Chironomus riparius tests}

Temperature was constant $\left(21+/-1^{\circ} \mathrm{C}\right)$ so as $\mathrm{pH}(7.9+/-0.3)$. Conductivity was $490+/-$

$22535 \mu \mathrm{S} \mathrm{cm}^{-1}$, and the percentage of dissolved oxygen was always above $90 \%$. Growth (length 226 of $12.1 \mathrm{~mm}$ at 7 days) and survival (72\%) in the control were enough to validate the test.

227 Chemical measurement showed a recovery of $63+/-4 \%$ for fluoxetine spiked on the 228 sediments. Traces of fluoxetine near detection limit $\left(0.1 \mathrm{mg} \mathrm{kg}^{-1}\right)$ were found in the control. 
There was no significant effect on Chironomus riparius growth, emergence and reproduction for concentrations up to $59.5 \mathrm{mg} \mathrm{kg}^{-1}$ (ANOVA, $\mathrm{p}>0.05$ ). Final length for all these concentrations were between 11.9 and $12.1 \mathrm{~mm}$ and total number of eggs per female were between 426 and 456. For measured concentration $666 \mathrm{mg} \mathrm{kg}^{-1}$, there was no emergence, survival at day 7 was low $(34 \%)$ and growth at day 7 was very significantly reduced $(\mathrm{p}<0.01$, Dunnet-t test), by $31 \%$.

\subsection{Hyalella azteca tests}

Temperature was constant $\left(20.9+/-0.4^{\circ} \mathrm{C}\right)$ so as $\mathrm{pH}(7.55+/-0.2)$. Conductivity was $391+/-17 \mu \mathrm{S} \mathrm{cm}^{-1}$, and the percentage of dissolved oxygen was always above $90 \%$.

No adult died for any of the concentrations during the test. There was no significant effect of fluoxetine on reproduction (ANOVA, $p>0.5$ ), with mean number of newborns per female from 12.8 to 15.9 . For the young organisms, more than $87.5 \%$ amphipods survived in all the concentrations. Effects on growth were significant for nominal concentration $100 \mu \mathrm{g} \mathrm{L}^{-}$

${ }^{1}$ at days 14, 21 and 28 ( $<<0.01$, Dunnet-t test), as presented by Figure 1. This resulted in a LOEC of $100 \mu \mathrm{g} \mathrm{L}^{-1}$ and a NOEC of $33 \mu \mathrm{g} \mathrm{L}^{-1}$. We used DEBtox models, with the three possible physiological modes of action for growth (effects on food assimilation, on growth energy costs or on maintenance energetic costs), and with a Von Bertalanffy growth rate of $0.08 \mathrm{~d}^{-1}$ (parameter required by the software, estimated with a least square method using control data). Growth was very low the first week, so we used DEBtox only from day 7 to 28 , but taking into account that compound accumulation has started from the very first day. The best fit was obtained for the mode of action "increase of energetic costs for growth", the two other modes of action leading to estimations significantly different from the data at day 28 obtained for nominal concentration $100 \mu \mathrm{g} \mathrm{L}^{-1}$. To propose a rough explanation for that, we should point that, in the DEBtox context, "increase of energetic costs for growth" is 
254 characterized by effects on growth rate but no effect on ultimate length. By looking at Figure

255 1, it seems that all growth curves tend to reach the same ultimate length. The NEC estimated

256 by DEBtox was $19 \mu \mathrm{g} \mathrm{L}^{-1}$, but the software was unable to provide a confidence interval,

257 which means that all numbers between 0 and infinity were in this confidence interval.

\subsection{Daphnia magna tests}

Temperature was constant $\left(19.9+/-0.34{ }^{\circ} \mathrm{C}\right)$ so as $\mathrm{pH}(7.9+/-0.27)$ and conductivity

$\left(642+/-30 \mu \mathrm{s} \mathrm{cm}^{-1}\right)$. Chemical measurements showed a recovery of fluoxetine in the exposure system from 80 to $102 \%$.

In the first test, a significant effect on growth was found at day 7 for concentrations 102 and $241 \mu \mathrm{g} \mathrm{L}^{-1}$. At days 14 and 21, this effect was only significant for exposure concentration $241 \mu \mathrm{g} \mathrm{L} \mathrm{L}^{-1}$. Moreover, there was $40 \%$ mortality for this concentration at day 21 and a significant decrease of reproduction by $32 \%$. No effect on reproduction was found for the other concentrations. The measurements of the newborns length for the third brood of the first test showed significant effects of fluoxetine for exposure concentrations 31,102 and $241 \mu \mathrm{g}$

$\mathrm{L}^{-1}$ (Figure 2). This parameter is the most sensitive to fluoxetine, resulting in a NOEC of 8.9 $\mu \mathrm{g} \mathrm{L}^{-1}$ and a LOEC of $31 \mu \mathrm{g} \mathrm{L}^{-1}$. Concerning the second test, effects were much more pronounced than for the first one, but with the same LOEC and NOEC. $70 \%$ of the newborns were found dead at $21 \mathrm{~d}$ for exposure concentration $102 \mu \mathrm{g} \mathrm{L}^{-1}$. Moreover, reproduction was

273 significantly reduced for exposure concentration $31 \mu \mathrm{g} \mathrm{L}^{-1}$ (by 18\%) and length was 274 significantly lower than the control for exposure concentrations 31 and $102 \mu \mathrm{g} \mathrm{L}^{-1}$. 
measurements showed a bad recovery of fluoxetine in the exposure system (from 27 to 69\%),

280 with measured exposure concentrations : 1, 4.2, 13 and $69 \mu \mathrm{g} \mathrm{L}^{-1}$.

281 There was no significant effect of fluoxetine on growth for all weekly measurements

282 (ANOVA, $\mathrm{p}>0.5$ ). As for reproduction, we observed a significant decrease at $69 \mu \mathrm{g} \mathrm{L}^{-1}$

283 (Figure 3) but no significant effect at lower concentrations (Dunnett-t tests, $\mathrm{p}<0.05$ ), resulting

284 in a NOEC of $13 \mu \mathrm{g} \mathrm{L}^{-1}$ and a LOEC of $69 \mu \mathrm{g} \mathrm{L} \mathrm{L}^{-1}$. We used DEBtox models to analyse data

285 on reproduction. We selected the physiological mode of action « increase of the energetic

286 costs of reproduction ». Indeed, the selection of effects on reproduction due to effects on

287 growth would have no sense here, because we exposed adults. We obtained a NEC of $5 \mu \mathrm{g} \mathrm{L}^{-1}$

288 with $95 \%$ confidence interval 4.3-10.4 $\mu \mathrm{g} \mathrm{L}^{-1}$. All values in this confidence interval are lower

289 than the estimated NOEC.

\section{Discussion}

The chemical measures for the tests with daphnids and chironomids showed a correct

spiking with fluoxetine. In contrast, the chemical measurements for the tests snails showed an irregular, sometimes low efficiency of water spiking (especially for low concentrations), despite a continuous renewal of the solution. Recently Kwon and Armbrust (2006) have demonstrated that fluoxetine is hydrolitycally and photolytically stable in aqueous solutions including natural waters. Fluoxetine may thus not be degradated in our system. Our hypothesis is thus that fluoxetine, which is likely to sorb very quickly on the sediments, could

300 sorb very quickly on the fish food provided to the snails and the amphipods in our test or to 301 the plastic tubes of the renewing system. As the exposure system was the same for H. azteca as for $P$. antipodarum, and as the tests for the snails were performed immediately after the 
measured for snails exposure to fluoxetine are also valid for amphipods exposure to

305 fluoxetine. The NOEC of $33 \mu \mathrm{g} \mathrm{L^{-1 }}$ expressed in nominal concentration for growth of amphipods would be a NOEC of $13 \mu \mathrm{g} \mathrm{L}^{-1}$ expressed in measured concentration.

307 The classification of sensitivity for our species was quite different from our expectations based 308 on the works of Wogram and Liess (2001) on effects on organic compounds on invertebrates, 309 which classified amphipods, daphnids and snails in order of decreasing sensitivity, which

310 confirms the necessity to treat pharmaceuticals specifically among all organic compounds. In our 311 tests, the most sensitive species is $P$. antipodarum, with a NEC of $5 \mu \mathrm{g} \mathrm{L}^{-1}$ relative to 312 reproduction. Moreover, the effects of fluoxetine were on reproduction for daphnids and snails 313 (juveniles fitness and total amount of newborns respectively), whereas they were on growth for $314 H$. azteca. Our choice of tested species was consequently relevant to capture a large range of 315 different types of responses.

316 For daphnids, the highest effects were found on the development of the embryos, with smaller newborns resulting in significant effects on their future reproduction. Exposure to fluoxetine has thus consequences on the fitness of the newborns, which energy-based models like

319 DEBtox are not able to account for. Indeed, they assume that the total amount of energy 320 invested per newborn is not concentration dependent, so that newborns should have the same 321 length and ability to resist to toxic exposure. This suggests a direct action of fluoxetine on the 322 development of newborns, which may not be the consequence of energy depletion in the adult female. Consequently, no result from modeling was presented for daphnids toxicity tests, for 324 our models cannot account for fluoxetine mode of action. For H. azteca, the use of DEBtox models was also irrelevant. DEBtox was unable to provide a confidence interval, which 326 means that all numbers between 0 and infinity were in this confidence interval. This suggest that energy-based models like DEBtox are unable to account accurately for the observed 
effects, and that, probably, the main target of fluoxetine in $H$. azteca is not the dynamics of energy.

We can compare our results with other studies from the literature. Fluoxetine appeared to

331 have different effects on growth, fecundity and reproduction depending on species. The

332 freshwater snail $P$ antipodarum has shown to be the most sensitive invertebrate species for 333 reproduction as a NOEC of $3.2 \mu \mathrm{g} \mathrm{L}^{-1}$ (56 days) has been reported by Nentwig (2007). This is 334 very coherent with the NEC of $5 \mu \mathrm{g} \mathrm{L}^{-1}$ we found in this project. For H. azteca, fluoxetine treatments inhibited growth with a NOEC of $33 \mu \mathrm{g} \mathrm{L} \mathrm{L}^{-1}$ expressed in nominal concentration. Brooks et al. (2003) also showed an inhibition of growth due to fluoxetine exposure. We have contradictory results compared to the data from Flaherty and Dodson (2005) who found an

338 enhancement of reproduction for Daphnia magna exposed to a concentration of $36 \mu \mathrm{g} \mathrm{L}^{-1}$

339 fluoxetine. In contrast, our results are coherent with Brooks et al. (2003) who found a

340 reproduction decrease for Ceriodaphnia dubia with a NOEC of $56 \mu \mathrm{g} \mathrm{L}^{-1}$ and a LOEC of 112

$341 \mu \mathrm{g} \mathrm{L}^{-1}$. Henry et al. (2004) also found reproduction decrease for the same species with a

342 NOEC of $89 \mu \mathrm{g} \mathrm{L}^{-1}$ and a LOEC of $447 \mu \mathrm{g} \mathrm{L}^{-1}$. Nentwig (2007) found a LOEC of $1.12 \mathrm{mg} \mathrm{kg}^{-}$

$343{ }^{1}$ (measured value) when studied fluoxetine effects on $C$. riparius emergence which was

344 associated to a significant increase of number of eggs per clutch. However, he observed no

345 effect on growth for concentrations up to $5.86 \mathrm{mg} \mathrm{kg}^{-1}$ and he recommends confirming the 346 potential reduced emergence and increased clutch size observed after fluoxetine exposure. In

347 our study, we observed no effect for concentrations below $59 \mathrm{mg} \mathrm{kg}^{-1}$. Fluoxetine is

348 consequently very unlikely to have effects in the field on Chironomus riparius.

349 To conclude, data sets on acute and chronic toxicity of the selected case study

350 pharmaceuticals have been derived in our study. Fluoxetine seems to interact with growth and 351 reproduction processes in invertebrates. Depending on the tested species, effects of fluoxetine 352 can be found at low exposure concentrations, around $10 \mu \mathrm{g} \mathrm{L}^{-1}$. The fact that the second 
generation of daphnids was more sensitive than the first one highlights the need for investigation of the effects of pharmaceuticals on at least two generations of invertebrates. Energy-based models were developed and used to describe effects on growth and reproduction, but were not relevant to estimates threshold effect for fluoxetine.

\section{Acknowledgements}

The present work is part of the project ERAPharm that is funded within the $6^{\text {th }}$ framework programme of the European Commission (Project $N^{\circ}$ SSPI-CT-2003-511135). We also would like to thank an anonymous reviewer who contributed to improve the reading of the manuscript.

\section{References}

Brooks, B.W., Turner, P.K., Stanley, J.K., Weston, J.J., Glidewell, E.A., Foran, C.M., Slattery, M., La Point, T.W., Huggett, D.B., 2003. Waterborne and sediment toxicity of fluoxetine to select organisms. Chemosphere 52, 135-142.

Carlsson, C., Johansson, A.K., Alvan, G., Bergman, K., Kuhler T., 2006. Are pharmaceuticals potent environmental pollutants? Part I: Environmental risk assessments of selected active pharmaceutical ingredients. Sci. Total Environ. 364, 67-87.

Fent, K., Weston, A.A., Caminada, D. ,2006. Ecotoxicology of human pharmaceuticals. Aquat.Toxicol. 76, 122-159.

Ferrari, B., Mons, R., Vollat, B., Fraysse, B., Paxéus, N., Lo Giudice, R., Pollio, A., Garric, J., 2004. Environmental risk assessment of six human pharmaceuticals: are the current environmental risk assessment procedures sufficient for the protection of the aquatic environment ? Environ. Toxicol. Chem. 23, 1344-1354. 
378 Flaherty, C.M., Dodson, S.I., 2005. Effects of pharmaceuticals on Daphnia survival, growth

379 and reproduction. Chemosphere 61, 200-207.

380 Henry, T.B., Kwon, J.W., Armbrust, K.L., Black, M.C., 2004. Acute and chronic toxicity of

381 five selective serotonin reuptake inhibitors in Ceriodaphnia dubia. Environ. Toxicol. Chem.

$382 \quad 23,2229-2233$.

383 Kooijman, S.A.L.M., Bedaux, J.J.M., 1996. The analysis of aquatic toxicity data. V.U.

384 University press, Amsterdam.

385 Kooijman, S.A.L.M., 2000. Dynamic energy and mass budgets in biological systems.

386 Cambridge University press, Cambridge.

387 Kolpin, D.W., Furlong, E.T., Meyer, M.T., Thurman, E.M., Zaugg, S.D., Barber, L.B.,

388 Buxton, H.T., 2002. Pharmaceuticals, hormones, and other organic wastewater contaminants

389 in U.S. streams 1999-2000: a national reconnaissance. Environ. Sci. Tech. 36, 1202-1211.

390 Kwon, J.W., Armbrust, K.L., 2006. Laboratory persistence and fate of fluoxetine in aquatic

391 environments. Environ. Toxicol. Chem. 25, 2561-2568.

392 Nentwig, G., 2006. Effects of pharmaceuticals on aquatic invertebrates. Part II: the

393 antidepressant drug fluoxetine. Arch. Environ. Contamin. Toxicol. 52, 163-170.

394 OECD., 2004. OECD guideline for the testing of chemicals No. 218: sediment-water

395 chironomid toxicity test using spiked sediment.

396 OECD., 2006. OECD environment health and safety publications. Series on testing and

397 assessment $n^{\circ} 54$ : current approaches in the statistical analysis of ecotoxicity data: a guidance

398 to applications.

399 Péry, A.R.R., Mons, R., Flammarion, P., Lagadic, L., Garric, J., 2002. A modelling approach

400 to link food availability, growth, emergence, and reproduction for the midge Chironomus

401 riparius. Environ. Toxicol. Chem. 21, 2507-2513. 
402 Péry, A.R.R., Ducrot, V., Mons, R., Garric, J., 2003. Modelling toxicity and mode of action of 403 chemicals to analyse growth and emergence tests with the midge Chironomus riparius. Aquat. 404 Toxicol. 65, 281-292.

405 Péry, A.R.R., Dargelos, S., Quéau, H., Garric, J., 2005. Preparatory work to propose water406 only tests with the amphipod Hyalella azteca. Comparison with sediment toxicity tests. Bull. 407 Environ. Contamin. Toxicol. 75, 617-622.

408 Wogram, J., Liess, M., 2001. Rank ordering of macroinvertebrate species sensitivity to toxic 409 compounds by comparison with that of Daphnia . Bull. Environ. Contamin. Toxicol. 67, 360410367. 
413 Figure 1. Length of the young $H$. azteca as a function of time and nominal concentration

414 (control : black diamonds, $1.2 \mu \mathrm{g} \mathrm{L}^{-1}$ : black squares, $3.7 \mu \mathrm{g} \mathrm{L}^{-1}$ : black triangles, $11 \mu \mathrm{g} \mathrm{L}{ }^{-1}$ :

415 white squares, $33 \mu \mathrm{g} \mathrm{L}^{-1}$ : white triangles, $100 \mu \mathrm{g} \mathrm{L}^{-1}$ : white diamonds). Asterisk accounts for 416 significant difference with the control $(\mathrm{p}<0.05$, Dunnet-t test).

417 Figure 2. Length of Daphnia newborns from the third brood as a function of fluoxetine 418 nominal concentration. Asterisk indicates significant difference from the control $(\mathrm{p}<0.05$, 419 Dunnett-t test).

420 Figure 3. Number of newborns per $P$. antipodarum adult (mean value and standard deviation) as 421 a function of fluoxetine nominal concentration. Asterisk indicates significant difference from the 422 control ( $\mathrm{p}<0.05$, Dunnett-t test). 


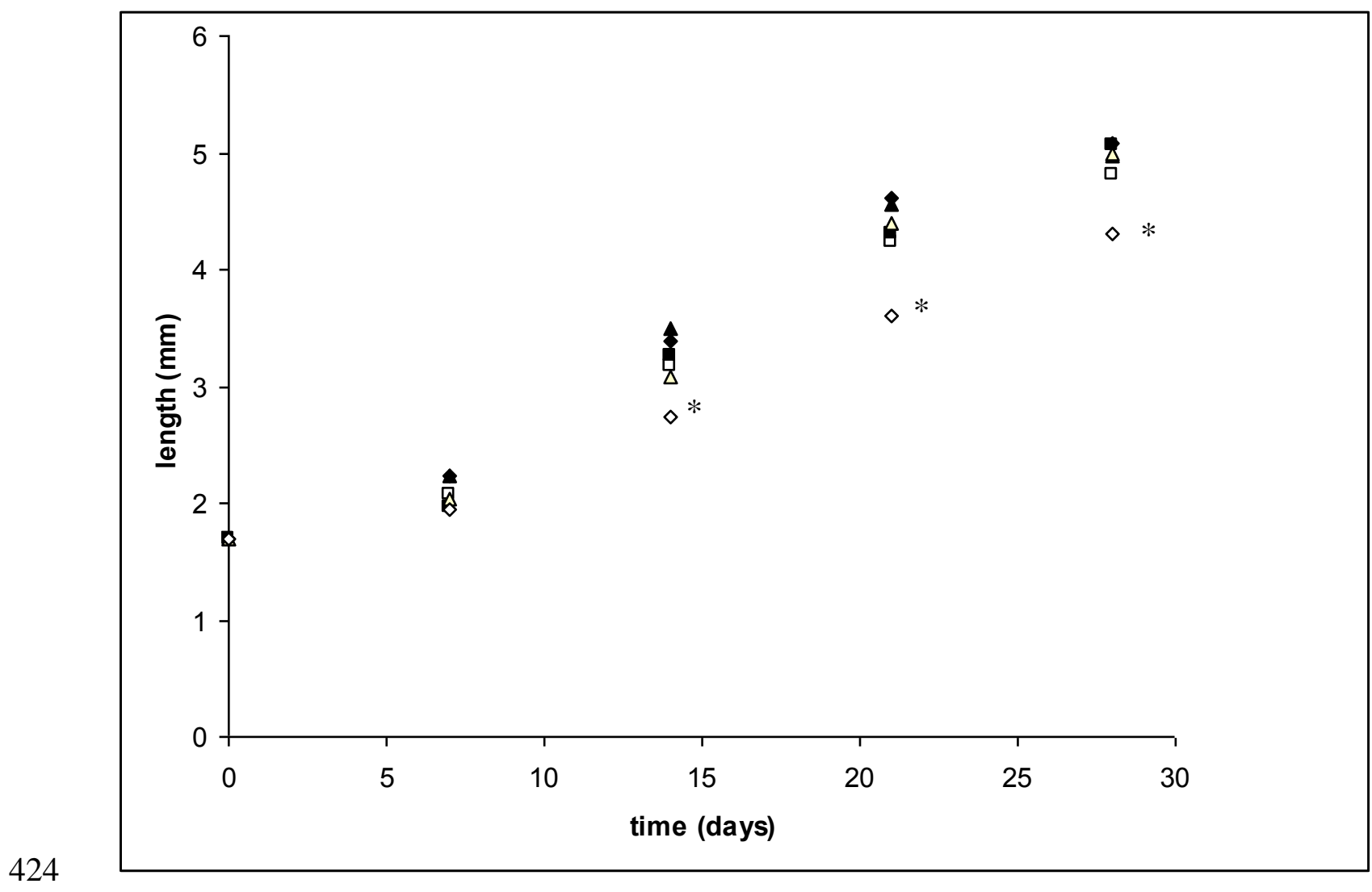

425 Figure 1.

426 


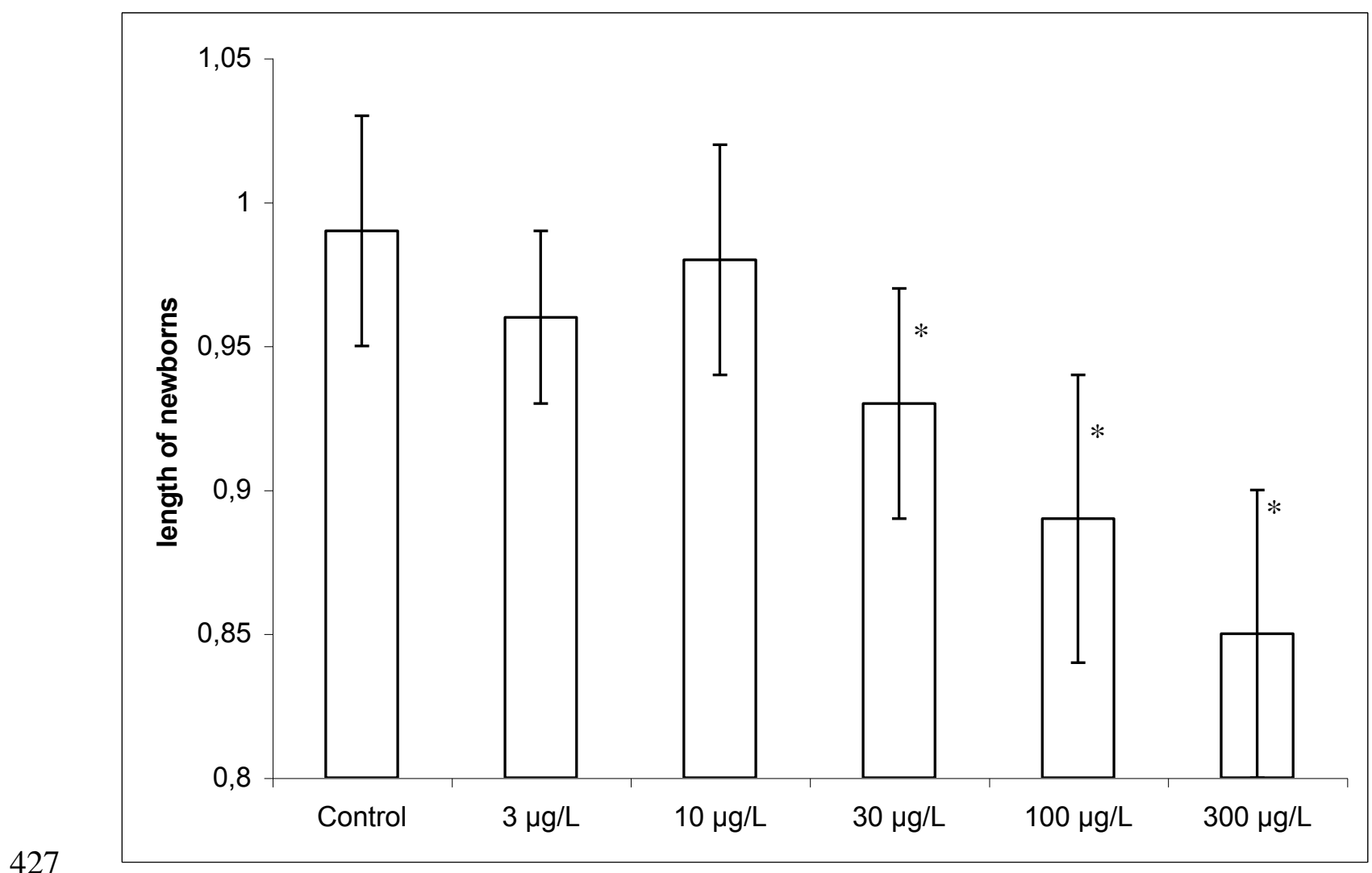

428 Figure 2.

429 


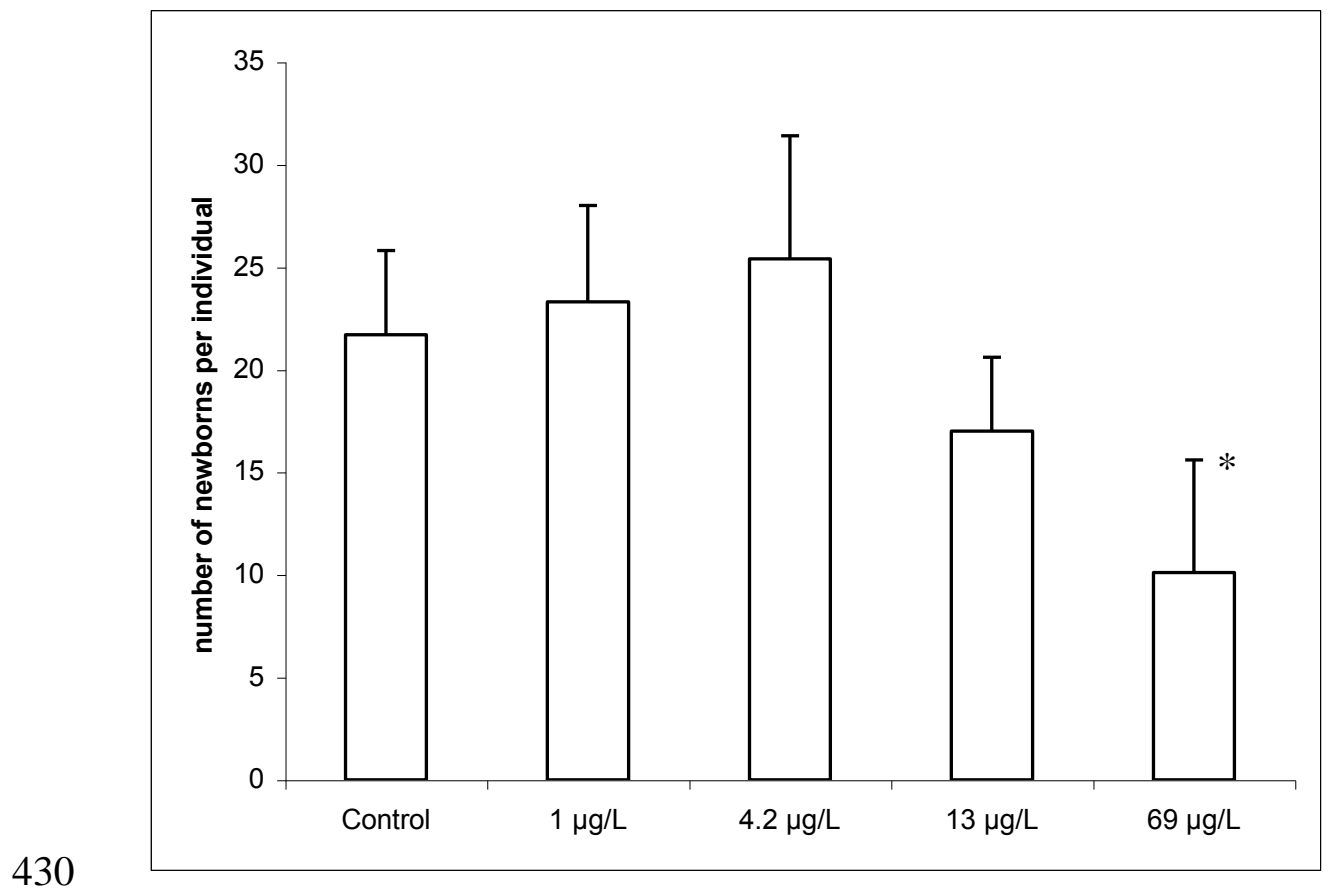

431 Figure 3.

432 